\title{
Socio-Economic Role of the Agriculture in the Development of the Rural Family in Biala District in Kafr El-Sheikh and Nabroh District in Dakahlia Governorate
}

Abo El-Saoud, $M$.

Agricultural Extension\& Rural Development Research Institute (AERDRI)-Agricultural Research Center
الدور الإجتماعى والإقتصادى للزراعة في تنمية الأسرة الريفية بمركزى بيلا بمحافظة كفر الثيخ ونبروة بمحافظة

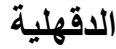

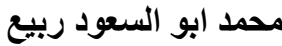
معه بحوث الارشاد الزراعى و البعو التنمية الريفيةـ مركز البحوث الزراعية
الملخص

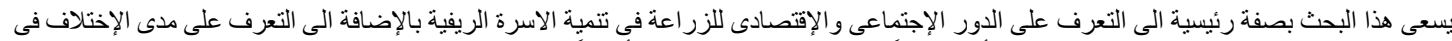

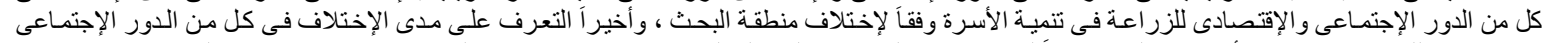

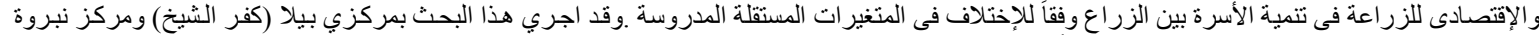

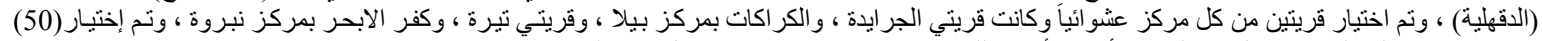

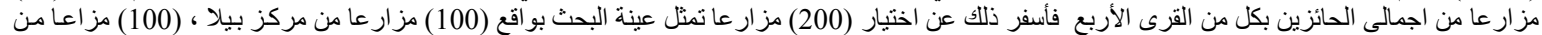

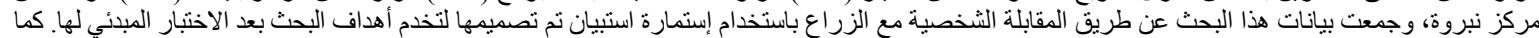

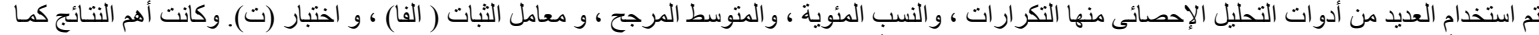

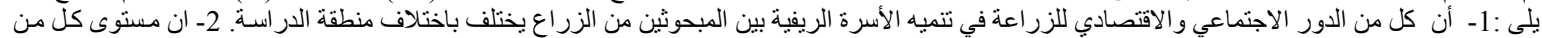

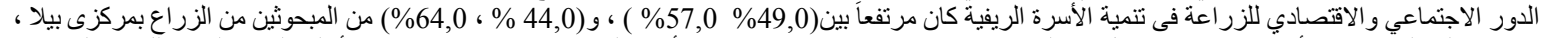

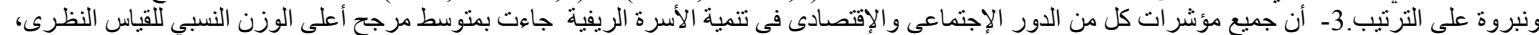

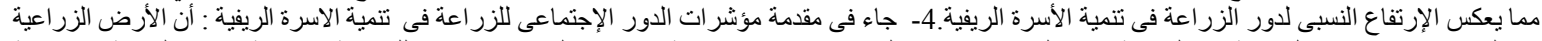

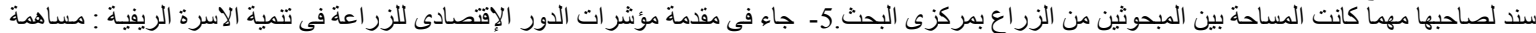

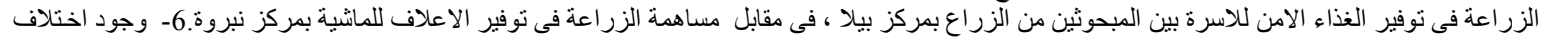

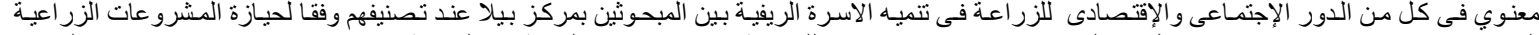

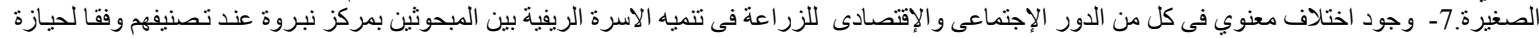
المشرو عات الزر اعية الصغيرة ، والزر اعة هى المصدر الرئيسى لدخل الاسرة ، و اخير الزئر الزراعة هى المهنة الاساسية للاسرة.

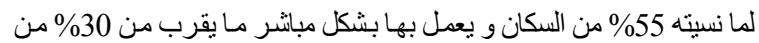

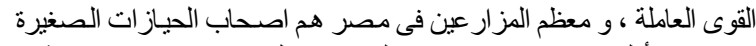

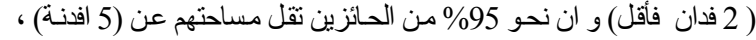

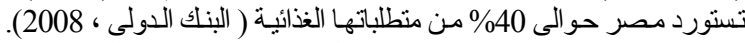

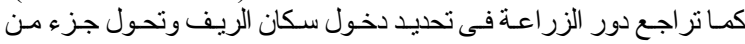

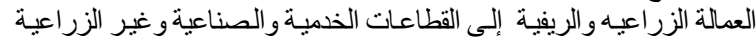

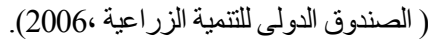

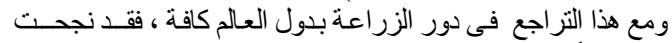

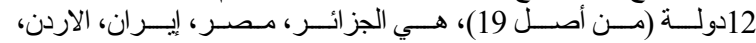

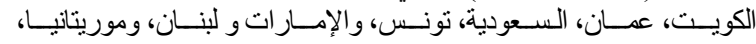

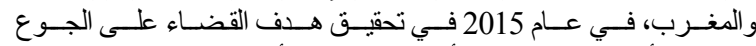

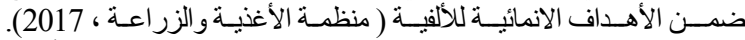

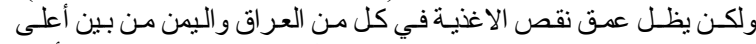

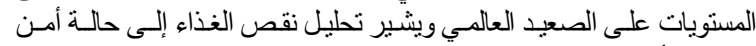

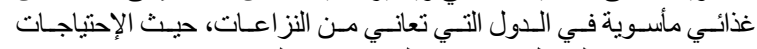

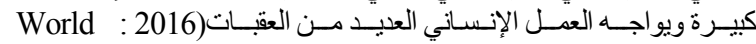

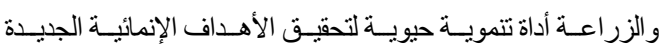

(Bank

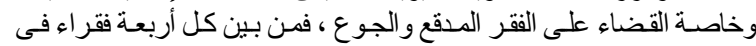

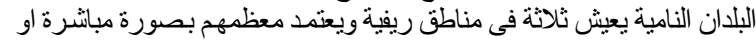

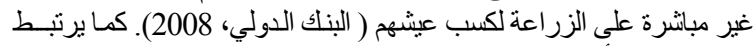

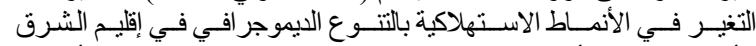

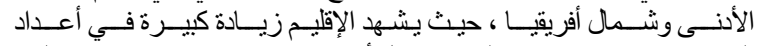

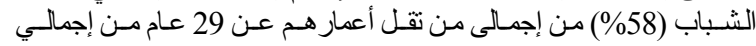

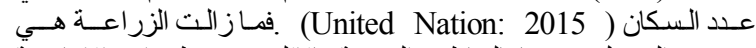

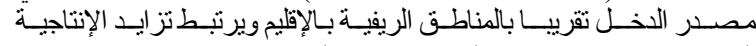

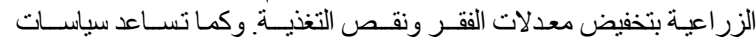

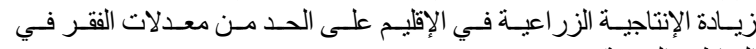
المناطف الريفية)(World Bank, 2014).

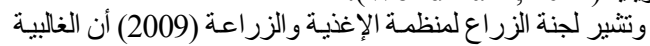

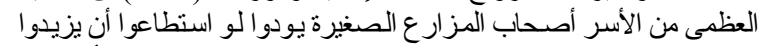

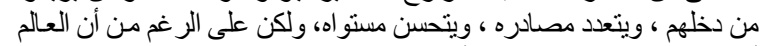

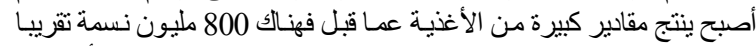
يعانون من سوء التغذية الحاد، بالإضافة إلى 2000 مليون يعانون من أمر اض
المقدمة واعهة

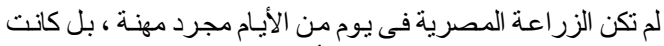

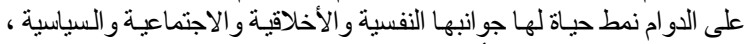

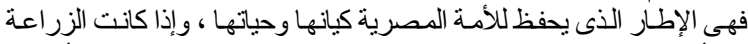

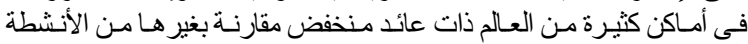

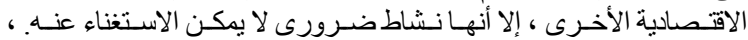

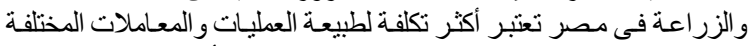

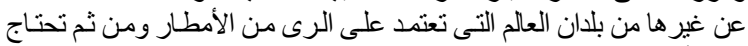

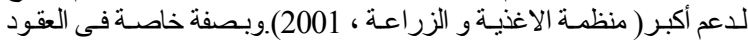

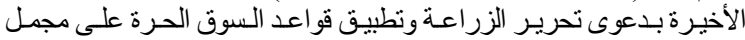

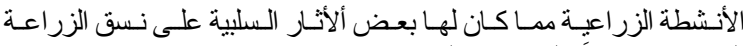
المصرية وخاصاً على صغار المزار الزعين.

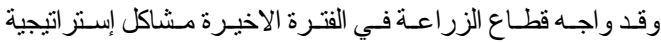

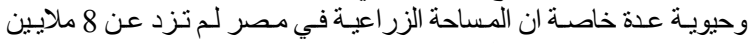

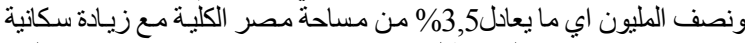

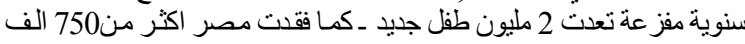

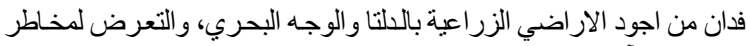

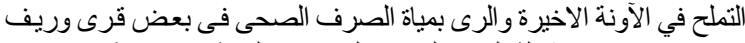

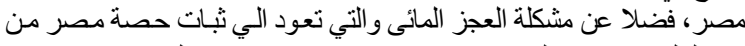

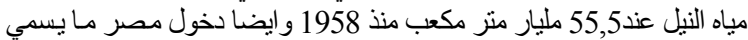

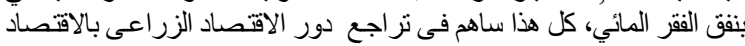

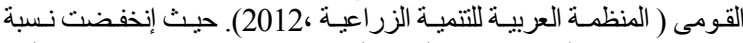

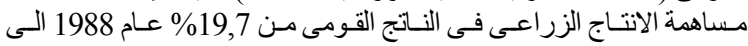

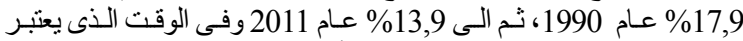

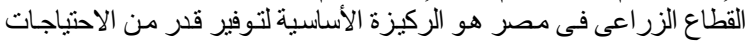

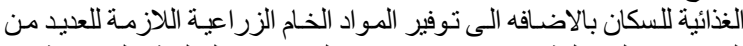

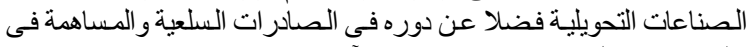

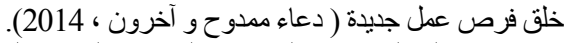

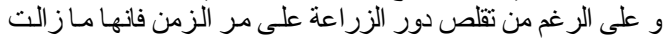

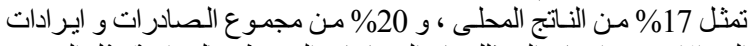

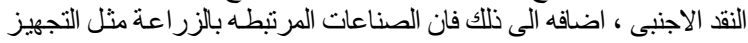

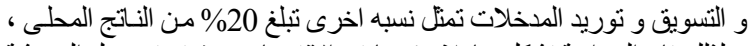

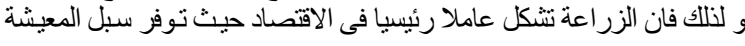


و على الرغم من الجهود الكبيرة المبذولة من طرف العديد من الدول

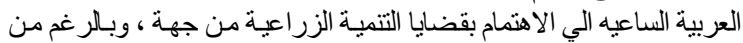

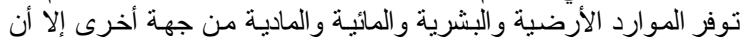

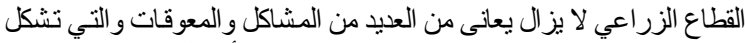

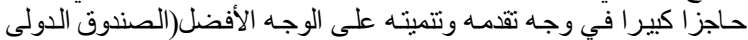

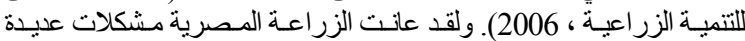

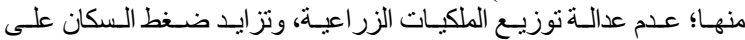

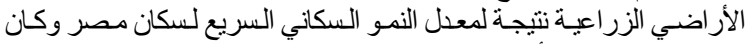

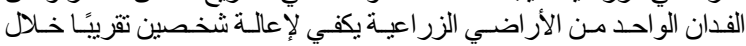

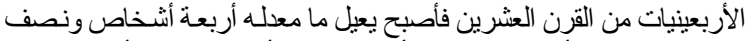

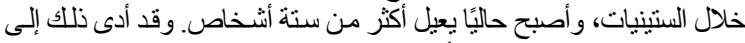

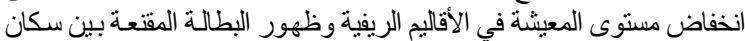

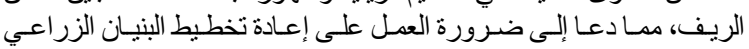

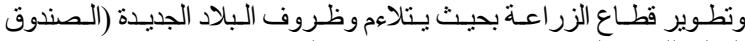

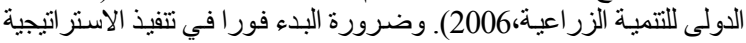

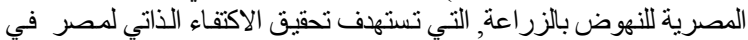

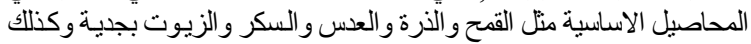

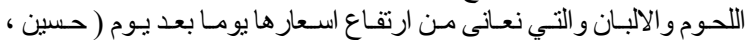

ونظر الأهمية هذا القطاع ركز البنك الدولي في تقريرة عن التنمية (1995

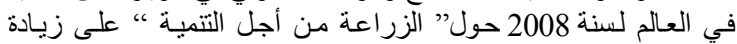

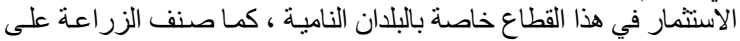

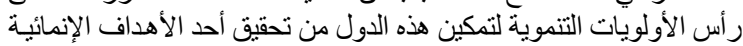

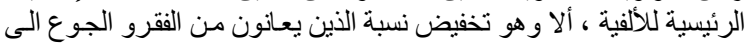

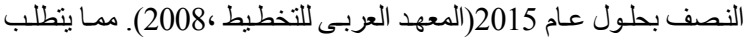

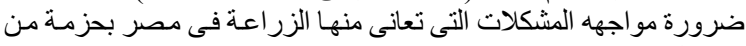

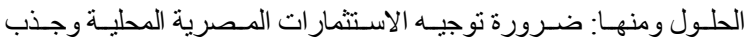

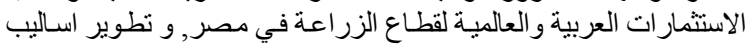

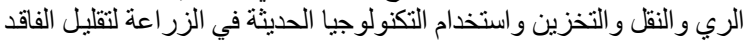

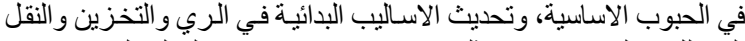

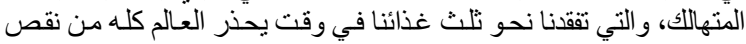

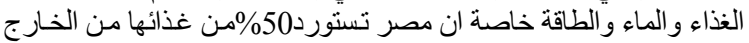

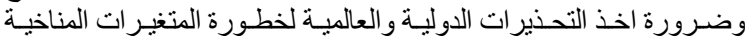

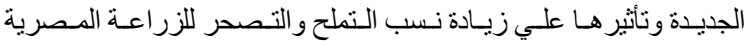

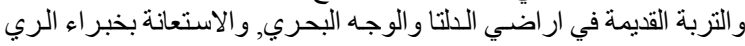

و والار اضي ( حسين ، 1995).

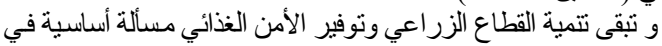

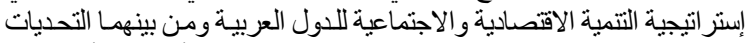

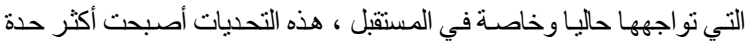

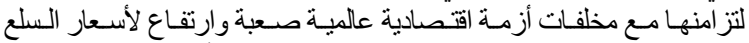

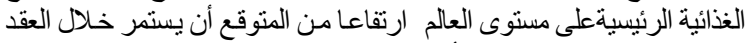

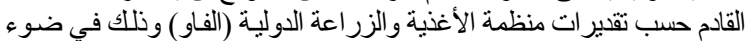

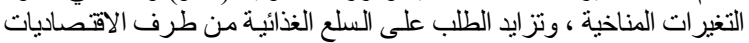

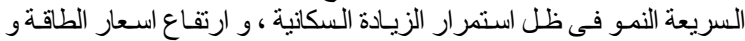

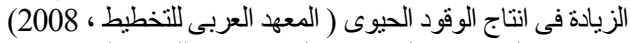

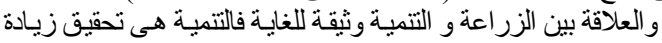

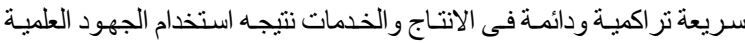

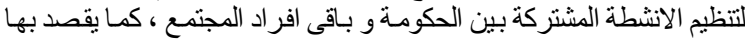

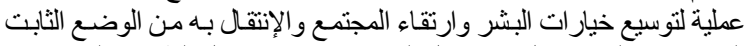

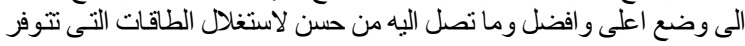

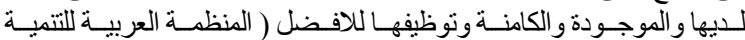

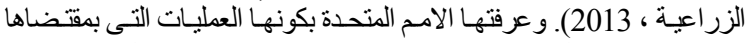

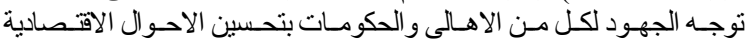

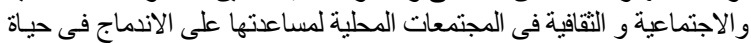

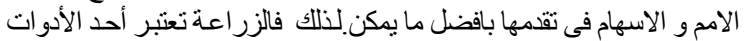

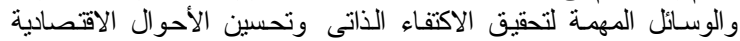

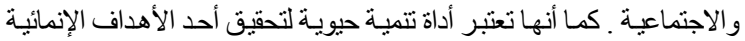

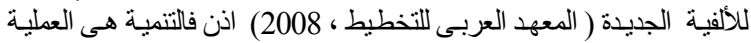

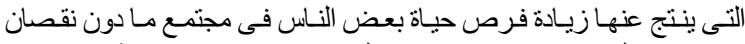

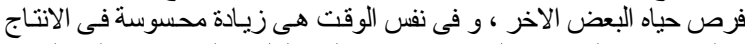

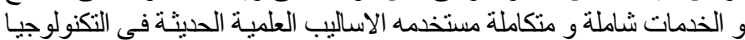

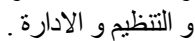

مختلفة ناجمـة عن نقص التغذيـة. فـالفقر الريفي و انعـدام الأمن الغذائي مـاز الا

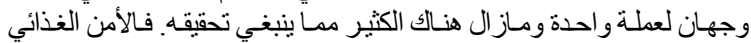

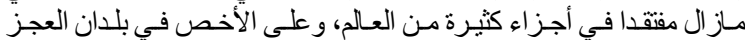

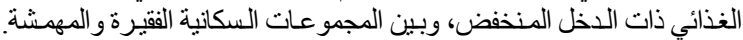

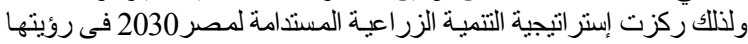

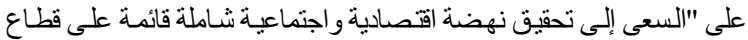

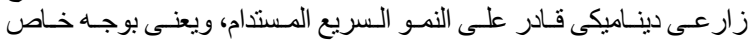

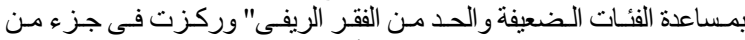

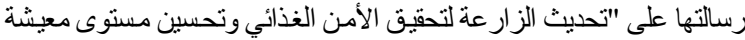

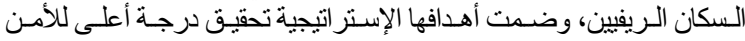

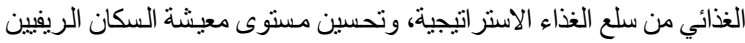

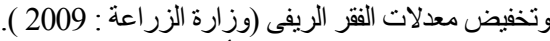

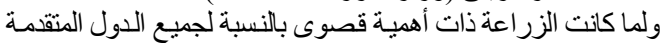

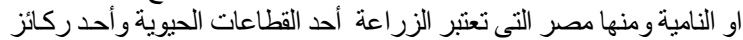

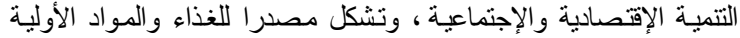

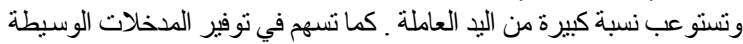

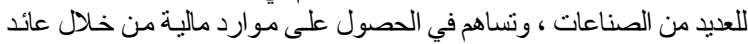

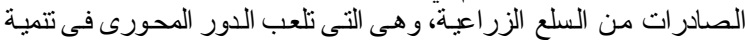

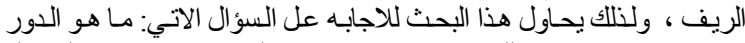

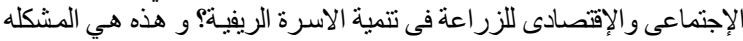

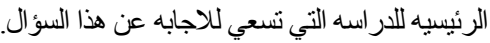

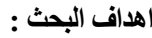

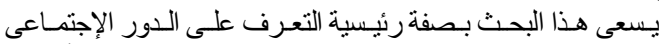

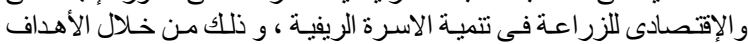

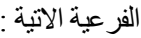

1. التعرف على الدور الإجتماعى للزر اعة فى تتمية الاسرة الريفية.

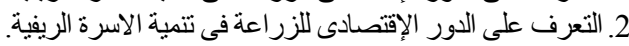

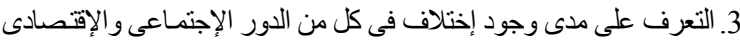

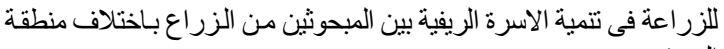<smiles>[Li]</smiles>

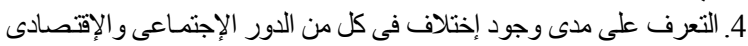

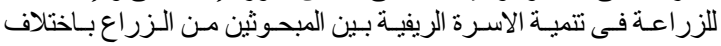
المتغير ات المستقلة المدروسة.

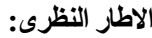

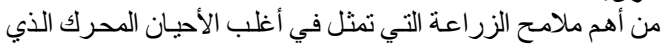

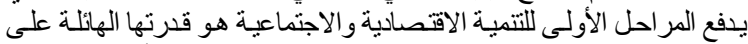

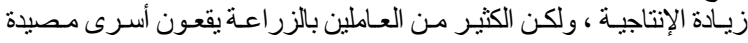

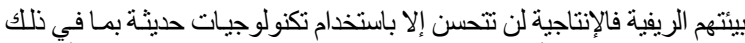

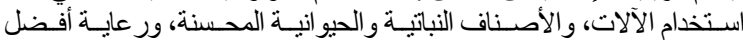

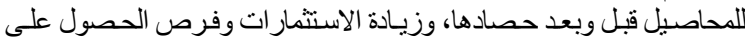

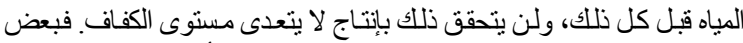

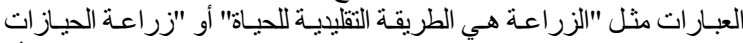

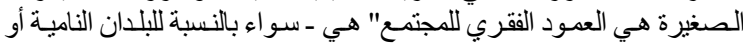

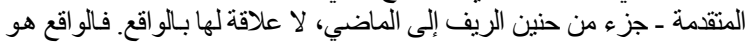

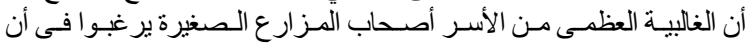

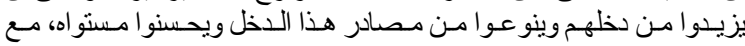

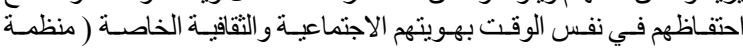

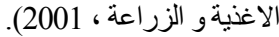

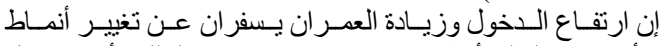

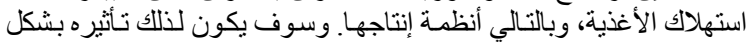

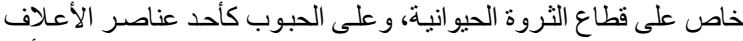

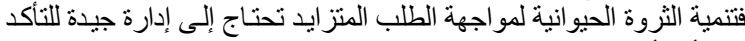

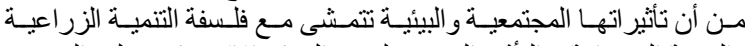

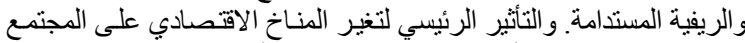

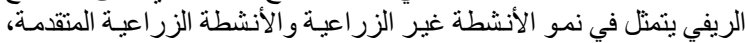

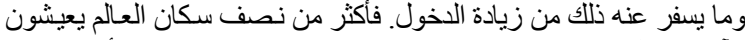

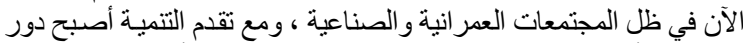

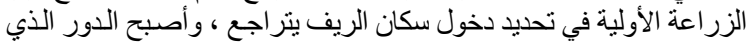

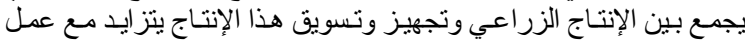

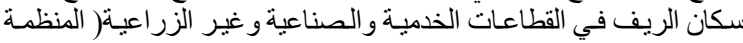
العربية للتنمية الزر اعية ،2012). 
و الرغبـة في عمل المشرو عات الصغيرة ، و الزر اعـة هـي المسصدر

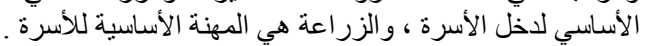

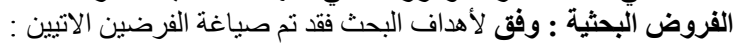

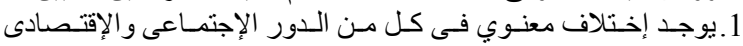

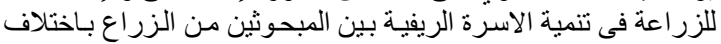
منطقة البحث.

2. يختلف الدور الإجتماعى والإقتصادى للزر اعة فى تتمية الاسرة الريفية بين

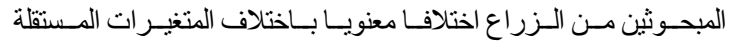
المدروسة.

و سوف يتم اختبار هنين الفرضين احصائيا فى صورتيهما الصفرية. النتائج

وسسوف يتم استعرض النتائج التي تم التوصل إليها وفقا لأهداف البحث كالأتي :

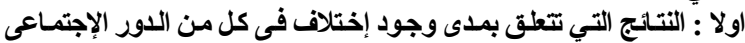

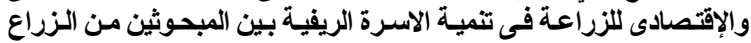

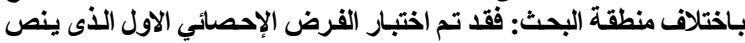

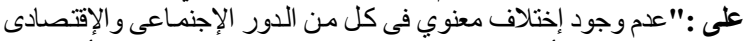

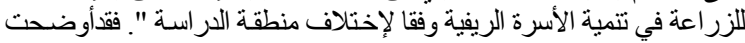

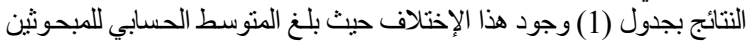

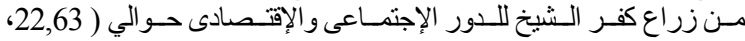

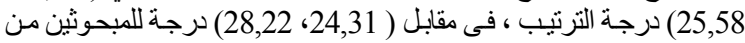

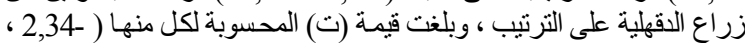

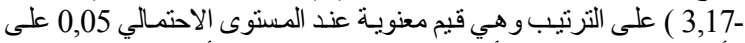

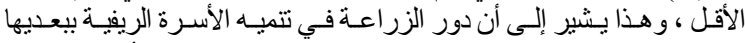

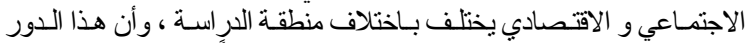

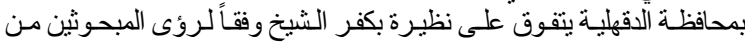

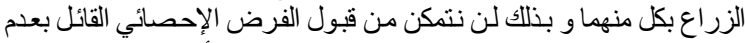

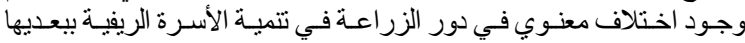

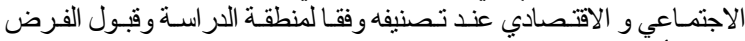

البديل.الأمر الذى يستدعى عرض النتائج على مستوى كل محافظة على حدة.

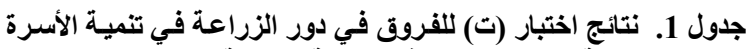

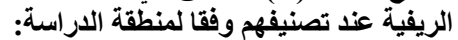

\begin{tabular}{|c|c|c|c|c|c|}
\hline \multirow{2}{*}{ قتيمة } & \multicolumn{2}{|c|}{ مركز نبروة } & \multicolumn{2}{|c|}{ مركز بيلا } & \multirow[b]{2}{*}{ البيان } \\
\hline & المعياري & الحستوسبي & المعياري & الحستوسي & \\
\hline & 5.33 & 24.31 & 4.79 & 22.63 & لإجتماعى \\
\hline$* * 3.1$ & 5.82 & 28.22 & 5.98 & 25.58 & \\
\hline
\end{tabular}

ثاثيا :النتاتج التي تتعلى بالدور الإجتماعى للزراعة في تتمية الأسرة الريفية:

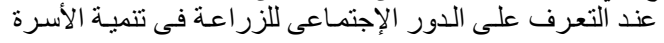

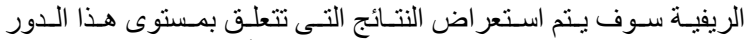

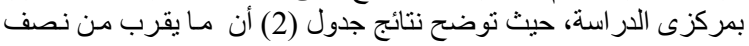

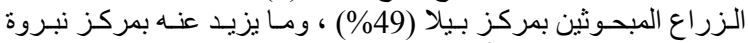

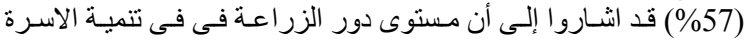

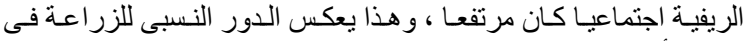

تنمية الأسرة الريفية اجتماعيا .

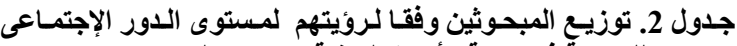

\begin{tabular}{|c|c|c|c|c|}
\hline \multicolumn{2}{|c|}{ مركز نبروة: } & \multicolumn{2}{|c|}{ مركز بيلا } & \multirow{2}{*}{ لفئات } \\
\hline$\%$ & العدد & $\%$ & العدد & \\
\hline 10 & 10 & 13 & 13 & منخفض (16درجة فأقل) \\
\hline 33 & 33 & 38 & 38 & متوسط (17-23) درجة \\
\hline 57 & 57 & 49 & 49 & مرتفع (24-30) درجة \\
\hline 100 & 100 & 100 & 100 & جمآلي \\
\hline
\end{tabular}

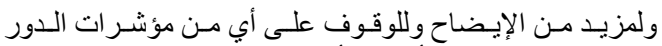

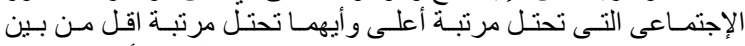

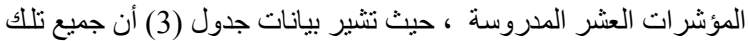

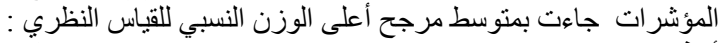

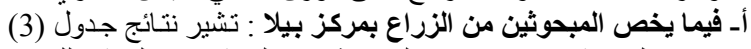

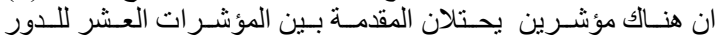

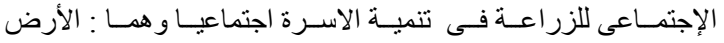
الزر اعية سند لصاحبها مهما كانت المساحة (2,51) درجة الاعة ، و مساهمة

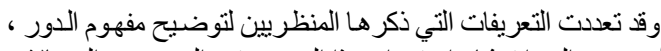

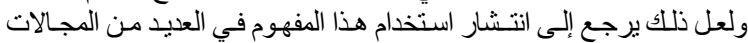

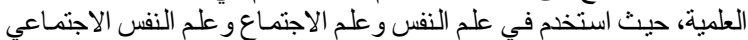

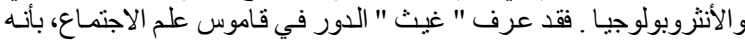

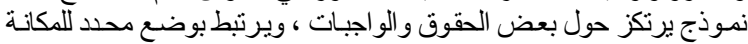

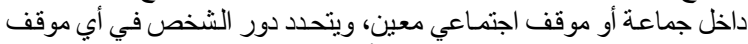

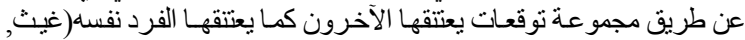

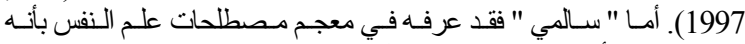

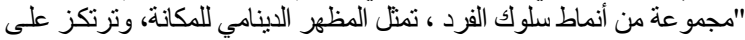

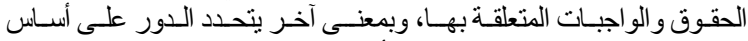

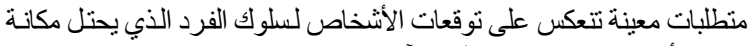

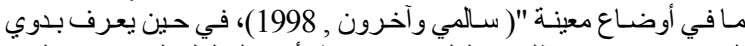

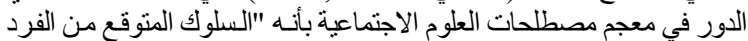

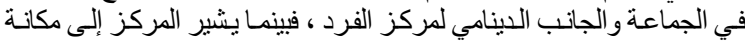

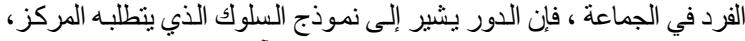

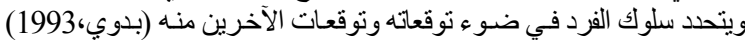

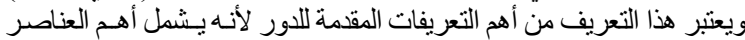

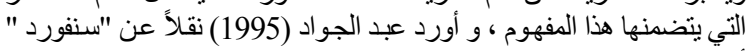

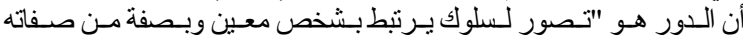

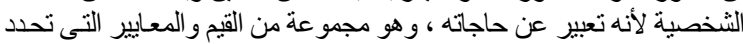

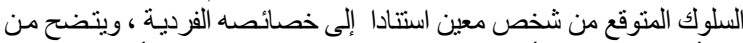

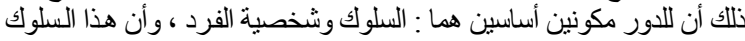

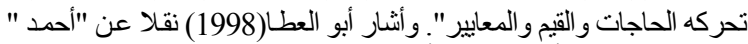

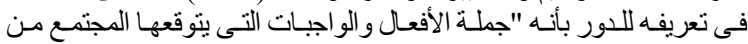

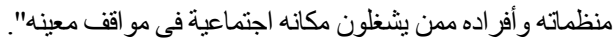

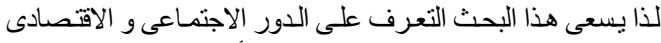

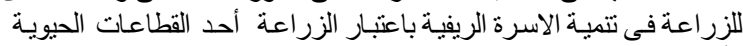

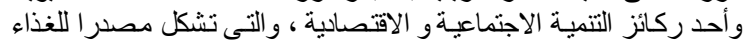

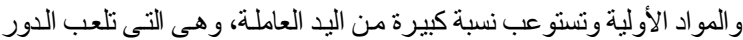
المحورى فى تتمية الريف

\section{الطريقة البحثية}

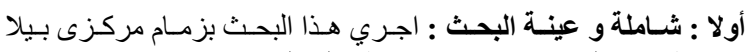

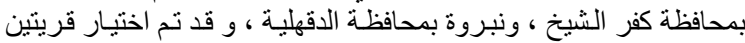

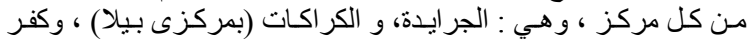

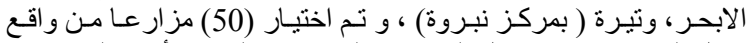

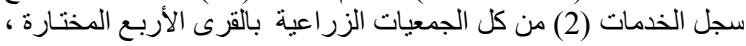

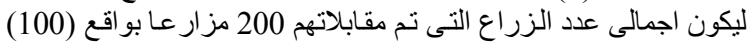

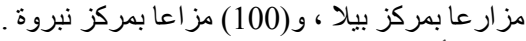
ثثاتيا : أسلوب جمع وتحليل البيانات:

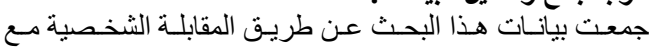

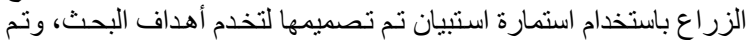

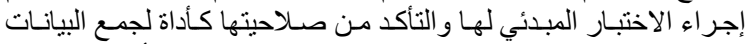

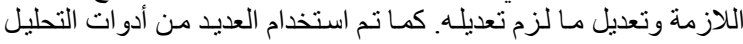

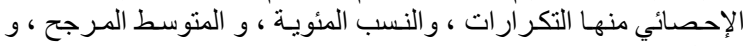

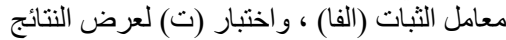

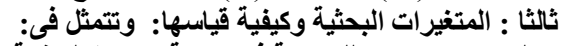

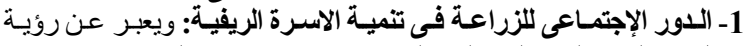

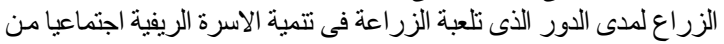

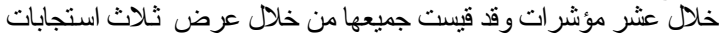

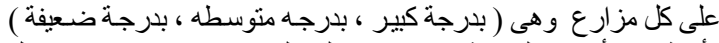

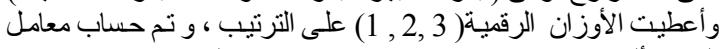

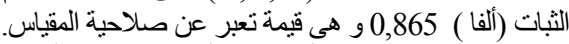

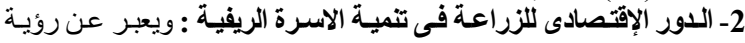

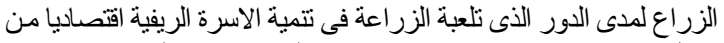

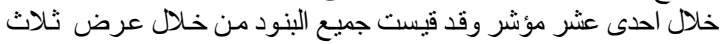

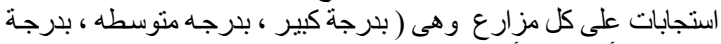

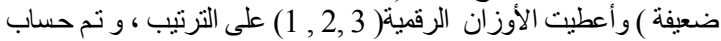

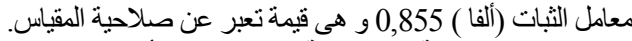

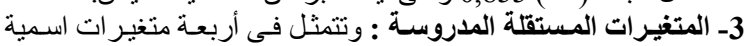

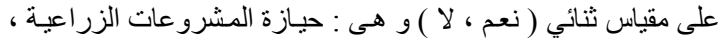




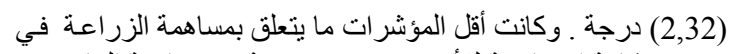

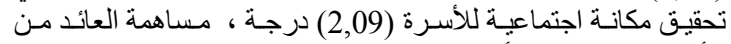

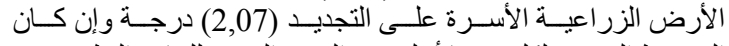
المتوسط المرجح لكل منهما أعلى من الوزن الوزن النسبى للقياس النظرى.

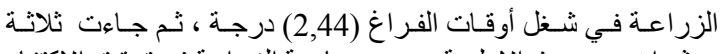

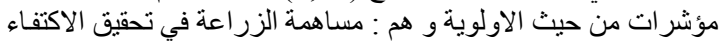

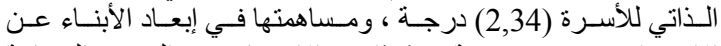

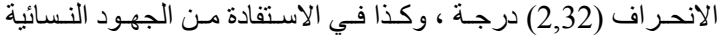

جدول3. توزيع المبحوثين وفقا لروئهم لمؤشرات الدور الإجتماعى الزراعة في تنمية الأسرة الريفية اجتماعيا بمركزى البحث.

\begin{tabular}{|c|c|c|c|c|c|c|}
\hline \multicolumn{4}{|c|}{ مركز نبروة (ن (100) } & \multicolumn{3}{|c|}{ بيلا (ن= (100) } \\
\hline م.مرجح & ضعيفة & متوسطه & كبيرة كبرة & م.مرجح & ضعيفة & b \\
\hline 2.28 & 26 & 20 & 54 & 2.44 & 17 & \\
\hline 2.43 & 13 & 31 & 56 & 2.14 & 19 & \\
\hline 2.37 & 15 & 33 & 52 & 2.24 & 21 & \\
\hline 2.23 & 27 & 23 & 50 & 2.32 & 15 & \\
\hline 2.14 & 32 & 22 & 46 & 2.32 & 19 & \\
\hline 2.53 & 20 & 7 & 73 & 2.09 & 26 & \\
\hline 2.53 & 7 & 33 & 60 & 2.34 & 15 & \\
\hline 2.84 & - & 16 & 84 & 2.51 & 2 & \\
\hline 2.56 & 10 & 24 & 66 & 2.16 & 22 & \\
\hline 2.40 & 10 & 40 & 50 & 2.07 & 24 & \\
\hline \multicolumn{7}{|c|}{ 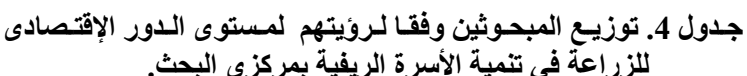 } \\
\hline \multicolumn{2}{|c|}{ الدقهلية } & \multicolumn{2}{|c|}{ كفر الثُشخخ } & \multirow{2}{*}{\multicolumn{3}{|c|}{ الفئات }} \\
\hline$\%$ & 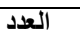 & $\%$ & العدد & & & \\
\hline 8 & 8 & 15 & 15 & جة فاقل) & $18)$ & 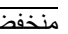 \\
\hline 28 & 28 & 41 & 41 & & -19) & 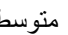 \\
\hline 64 & 64 & 44 & 44 & ) درجة & $3-27)$ & \\
\hline 100 & 100 & 100 & 100 & & & \\
\hline
\end{tabular}

ولمزيد من الإيضاح وللوقوف على أي مـن المؤشـرات تحتل مرتبـة

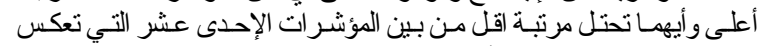

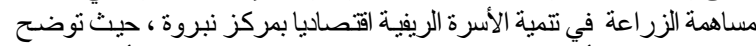

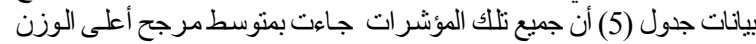

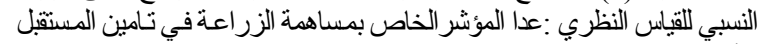

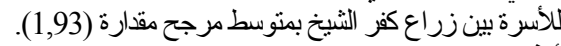

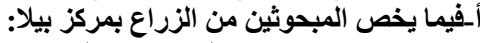

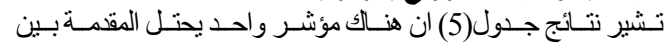

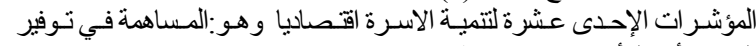

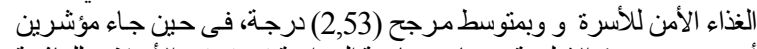

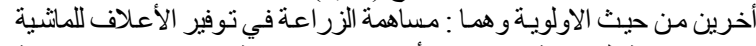

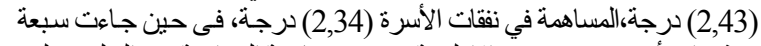

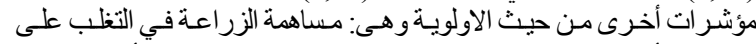

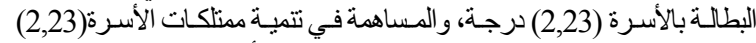

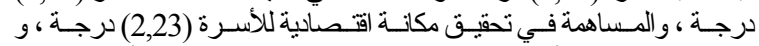

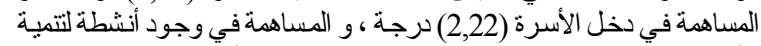

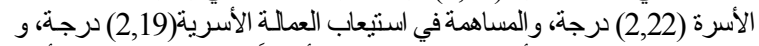

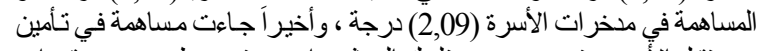

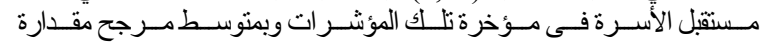

\begin{tabular}{|c|c|}
\hline & مساهمة الزراعة في تنمية الأسرة \\
\hline كبيزة & الريفية من حيث... \\
\hline 61 & المساهمة في شغل أوقات الفراغ. \\
\hline 33 & المساهمة في زواج الأبناء. ع. \\
\hline 45 & المساهمة في تعليم الأبناء. \\
\hline 47 & المساهمة في إبعاد الأبناء عن الا \\
\hline 51 & المساهمة في الاستفادة من الجهود النسائية. \\
\hline 35 & المساهمة في تحقيق مكانة اجتماعبة للأسرة. \\
\hline 49 & المساهمة في تحقيق الاكتفاء الذاتي للأسرة. \\
\hline 53 & الأرض الزرّ اعية سند لصاحبها مُهما كانت المساحة. \\
\hline 38 & المساهمة في إثباع رغبات أفر اد الأسرة. \\
\hline 31 & عائد الأرض الزر آعبة يساعد الأسرة على التجديد. \\
\hline
\end{tabular}

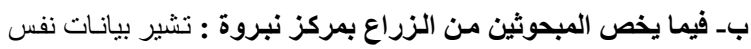

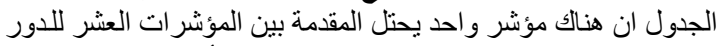

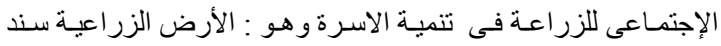

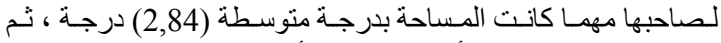

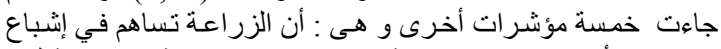

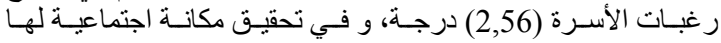

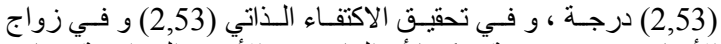

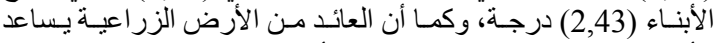

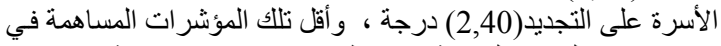

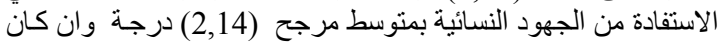
أكبر من الوزن النسبى للقياس النظرى.

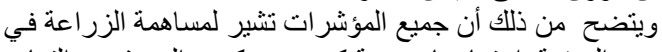

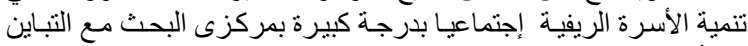

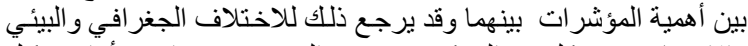
والاجتماعي بين كل من المركزين ، وبين الريفين ومعتقداتهم وأرائهر بكل

ثالثًاً ـالنتائج التى تتعلق باللاور الإقتصادى للزراعة فى تنمية الأسـرة الريفية:

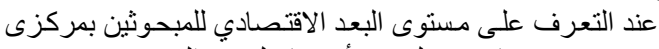

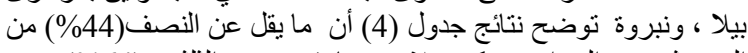

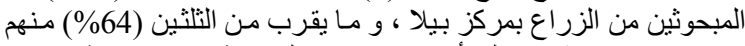

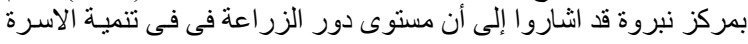

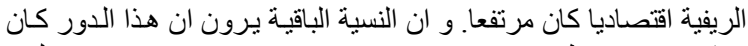

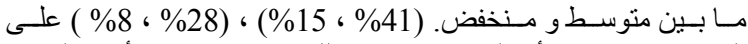
الترتيب. و هذا يعني أن الدور الإقتصادى للزر اعة في تنمية الأسرة الريفيـة لا يستهان به . (1,93 ) درجة.

جدول5 ـ توزيع المبحوثين وفقا لرويتهم لمؤشرات الاور الإقتصادى للزراعة في تنمية الأسرة الريفية بمركزى البحث.

\begin{tabular}{|c|c|c|c|c|c|c|c|c|}
\hline \multicolumn{4}{|c|}{ الاقهاية ن = } & \multicolumn{4}{|c|}{ كفر الشيخ ن = 100} & \multirow{2}{*}{ مساهمة الزراعة في تنمية الأسرة الريفية من حيث........ } \\
\hline م.مرجح & 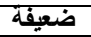 & متوسطه & كبيرة & م.مرجح & ضعيفة & متوسطة متر & كبيزة & \\
\hline 2.49 & 7 & 37 & 56 & 2.34 & 9 & 48 & 43 & ل في نفقات الاسرة. \\
\hline 2.49 & 8 & 35 & 57 & 2.22 & 14 & 50 & 36 & المساهم \\
\hline 2.38 & 14 & 34 & 52 & 2.23 & 23 & 31 & 46 & المساهمة \\
\hline 2.43 & 14 & 29 & 57 & 2.09 & 29 & 33 & 38 & المساهمة \\
\hline 2.44 & 16 & 24 & 60 & 2.23 & 15 & 47 & 38 & المساهمة في \\
\hline 2.47 & 15 & 23 & 62 & 2.23 & 21 & 35 & 44 & المساهمة في تحقيق مكانة اقتصادية للأسرة. \\
\hline 2.74 & 8 & 10 & 82 & 2.43 & 17 & 23 & 60 & المساهمة في تو فير الأعلاف للماثشية. \\
\hline 2.62 & 10 & 18 & 72 & 2.53 & 12 & 23 & 65 & المساهمة في توفير الغذاء الأمن للأسرة \\
\hline 2.33 & 14 & 39 & 47 & 2.19 & 18 & 45 & 37 & المساهمة في استيعاب العمالة الأسر \\
\hline 2.55 & 11 & 23 & 66 & 1.93 & 33 & 41 & 26 & المساعدة في تأمين منتقبل الأسرة. \\
\hline 2.30 & 19 & 32 & 49 & 2.22 & 19 & 40 & 41 & المساهمة في وجود أنشطة لتنميةً الأسرة. \\
\hline
\end{tabular}

و المساهمة في دخـل الأسـرة(2,49) درجـة ، و المسساهمة في تحقيـق مكانـة

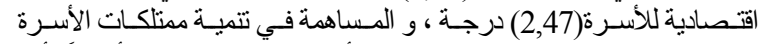

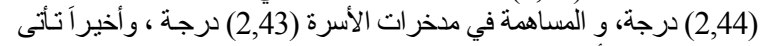

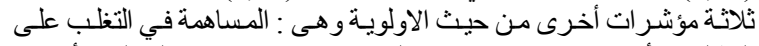

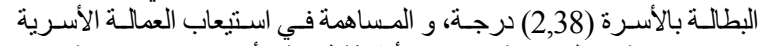

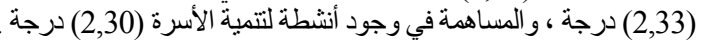

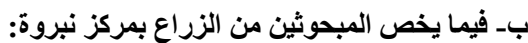

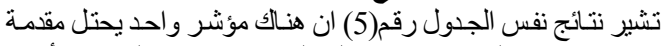

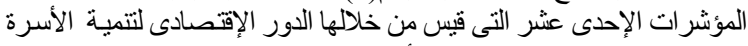

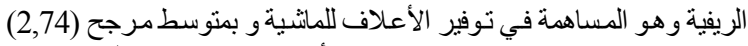

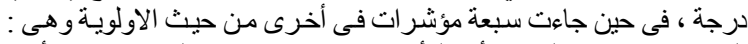

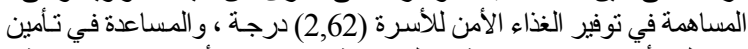

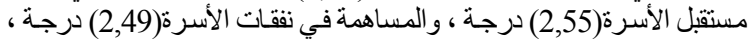


الإجتماعى و الإقتصادى للزر اعة في تنميـة الاسرة الريفية بين المبحوثين

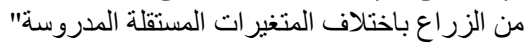

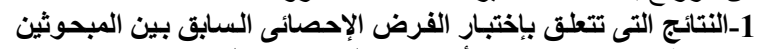

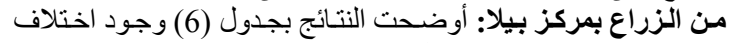

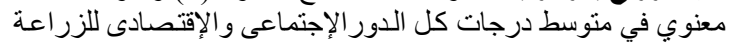

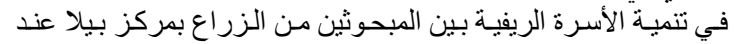

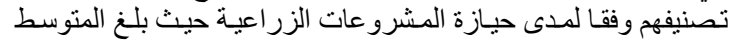

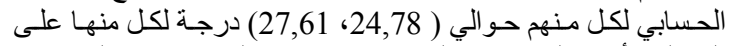

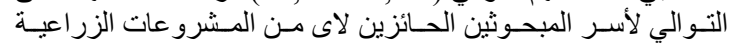

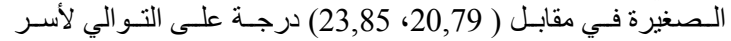

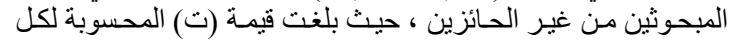

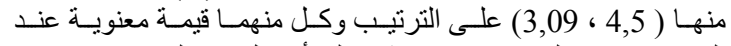

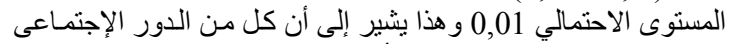

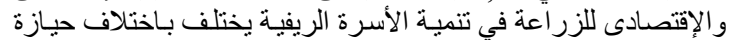
المشرو عات الزرادية الزراعة في لضيرة.

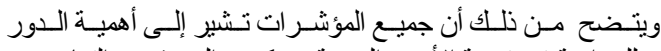

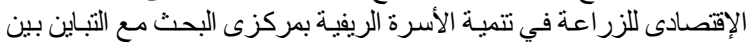

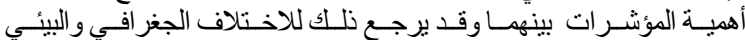
والاجتمـاعي بين كل من المركزين ، وبين الريفين ومعتقداتهم وأر ائهم بكل

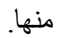

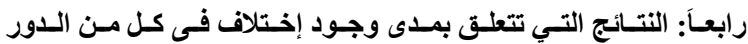

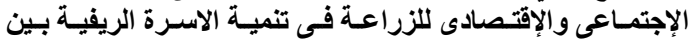

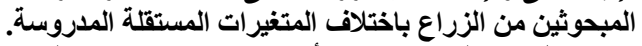

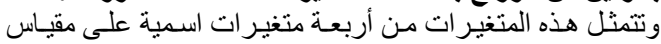

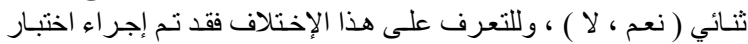

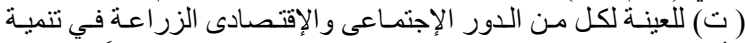

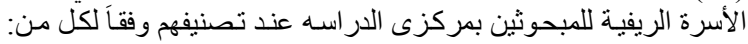

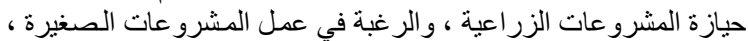

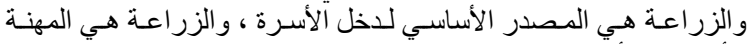

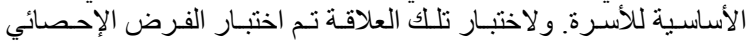

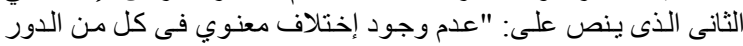

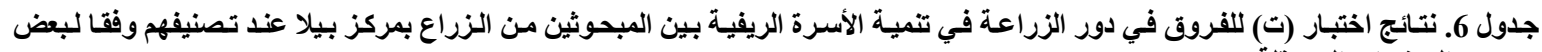

\begin{tabular}{|c|c|c|c|c|c|c|}
\hline & لاور الإنتصادي & & & لور الاجتماعى & & المتغيرات المستقلة : \\
\hline فيمة (ت) & الانحراف المغياري & المتوسط الحسابي & قيمة (ت) & الانحرَف المَبِياري & المتوسط الحسابي & المتغيرات الممستقلة \\
\hline$* * 3,09$ & $\begin{array}{l}4,60 \\
6,50 \\
\end{array}$ & $\begin{array}{l}27,61 \\
23,85 \\
\end{array}$ & $* * 4,5$ & $\begin{array}{l}3,42 \\
5,06\end{array}$ & $\begin{array}{l}24,78 \\
20,79 \\
\end{array}$ & 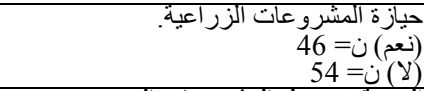 \\
\hline 0,69 & $\begin{array}{l}5,25 \\
6,48 \\
\end{array}$ & $\begin{array}{l}26,07 \\
25,22 \\
\end{array}$ & 0,65 & $\begin{array}{l}4,31 \\
5,15 \\
\end{array}$ & $\begin{array}{l}22,26 \\
22,89 \\
\end{array}$ & 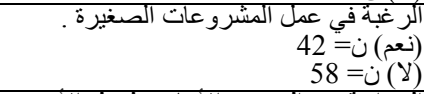 \\
\hline 0,75 & $\begin{array}{l}6,64 \\
4,37 \\
\end{array}$ & $\begin{array}{l}25,90 \\
24,94 \\
\end{array}$ & 0,19 & $\begin{array}{l}5,26 \\
3,77 \\
\end{array}$ & $\begin{array}{l}22,57 \\
22,76 \\
\end{array}$ & 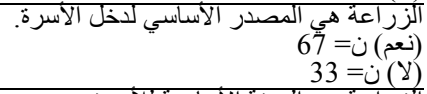 \\
\hline$* * 2,4$ & $\begin{array}{l}5,95 \\
5,25\end{array}$ & $\begin{array}{l}26,24 \\
22,56\end{array}$ & 1,11 & $\begin{array}{l}4,65 \\
5,44\end{array}$ & $\begin{array}{l}22,88 \\
21,50\end{array}$ & 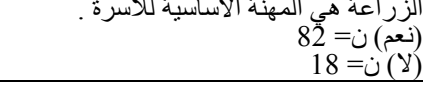 \\
\hline
\end{tabular}

معنوي في كل الدور الإجتمـاعى و الإقتصادى للزر اعـة في تنميـة الأسرة

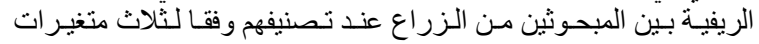

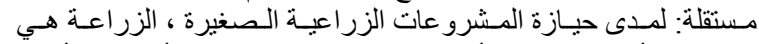

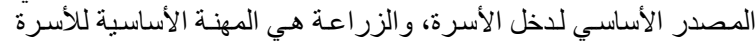

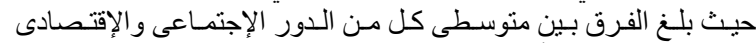

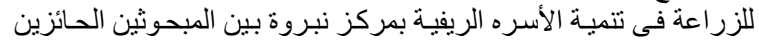

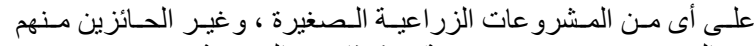

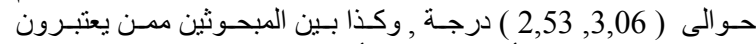

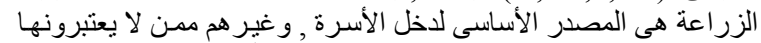

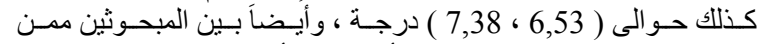

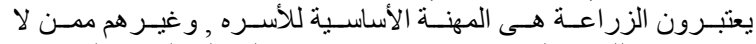

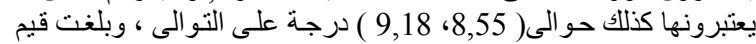

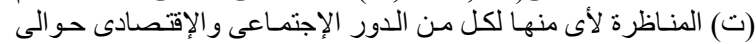

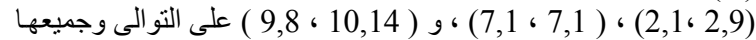

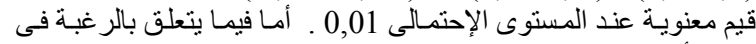

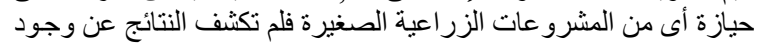

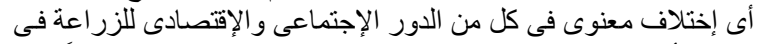

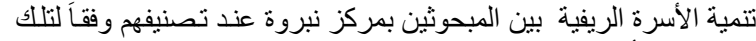
الرغبة عند أى مستوى إحتمالى يمكن قبولة الرئة
لم تكشف النتائج عن وجـود هذا الإختلاف في كل مـن من الدور

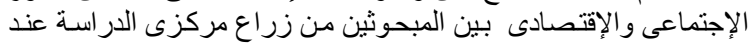

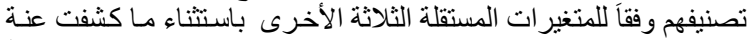

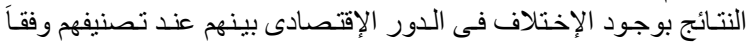

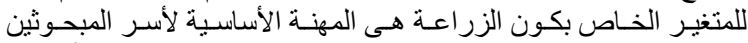

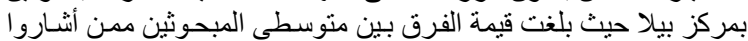

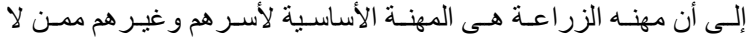

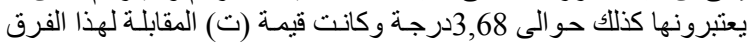

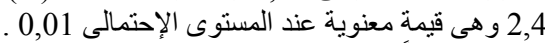

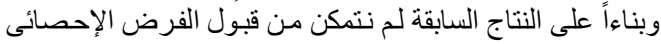

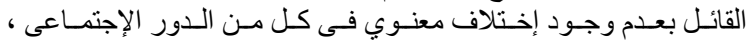

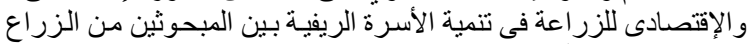

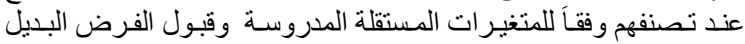

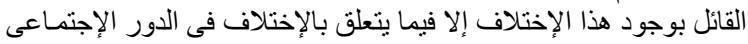

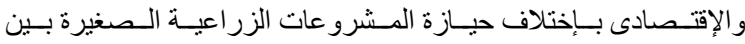

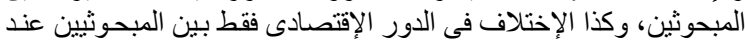

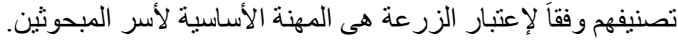

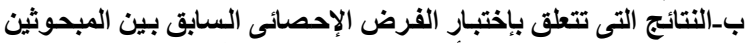

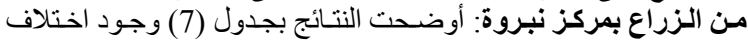

جدول 7. نتائج اختبار (ت) للفروق في دور الإجتماعى والإقتصادى للزراعة في تتمية الأسرة الريفية بين المبحوثين من الزراع بمركز نبروة عند تصنيفهم وفقا لبعض المتنغير (ت المرف في دور المستقلة :

\begin{tabular}{|c|c|c|c|c|c|c|}
\hline 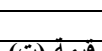 & الاور الأتصادي & t lo & 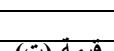 & دور الاجتماعي & 1 & لمتغيرات الممستقلة \\
\hline "فيمه (ت) & الاحراق المعياري & المتوسط الحسابي & قيمه (ت) & الاتحراف المعياري & المسوسط الحسابي & 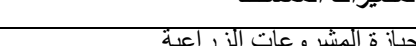 \\
\hline$* * 2,1$ & $\begin{array}{l}3,35 \\
6,36\end{array}$ & $\begin{array}{l}29,79 \\
27,26\end{array}$ & $* * 2,9$ & $\begin{array}{l}3,42 \\
5,94\end{array}$ & $\begin{array}{l}26,21 \\
23,15\end{array}$ & 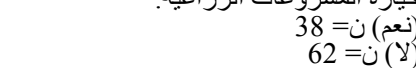 \\
\hline $0,31-$ & $\begin{array}{l}7,53 \\
4,78\end{array}$ & $\begin{array}{l}27,97 \\
28,35\end{array}$ & $0,65-$ & $\begin{array}{l}6,41 \\
4,69\end{array}$ & $\begin{array}{l}24,11 \\
24,42\end{array}$ & 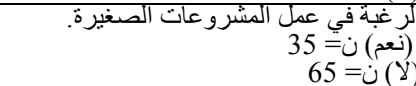 \\
\hline$* * 7,1$ & $\begin{array}{l}4,09 \\
5,61\end{array}$ & $\begin{array}{l}30,73 \\
23,35\end{array}$ & $* * 7,1$ & $\begin{array}{l}4,13 \\
4,75\end{array}$ & $\begin{array}{c}26,53 \\
20,0\end{array}$ & 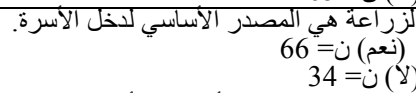 \\
\hline$* * 9,8$ & $\begin{array}{l}3,91 \\
4,74\end{array}$ & $\begin{array}{l}30,70 \\
21,52\end{array}$ & $* * 10,14$ & $\begin{array}{l}3,95 \\
3,09\end{array}$ & $\begin{array}{l}26,62 \\
18,07\end{array}$ & 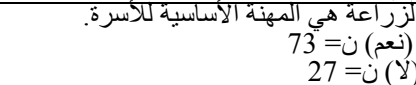 \\
\hline
\end{tabular}




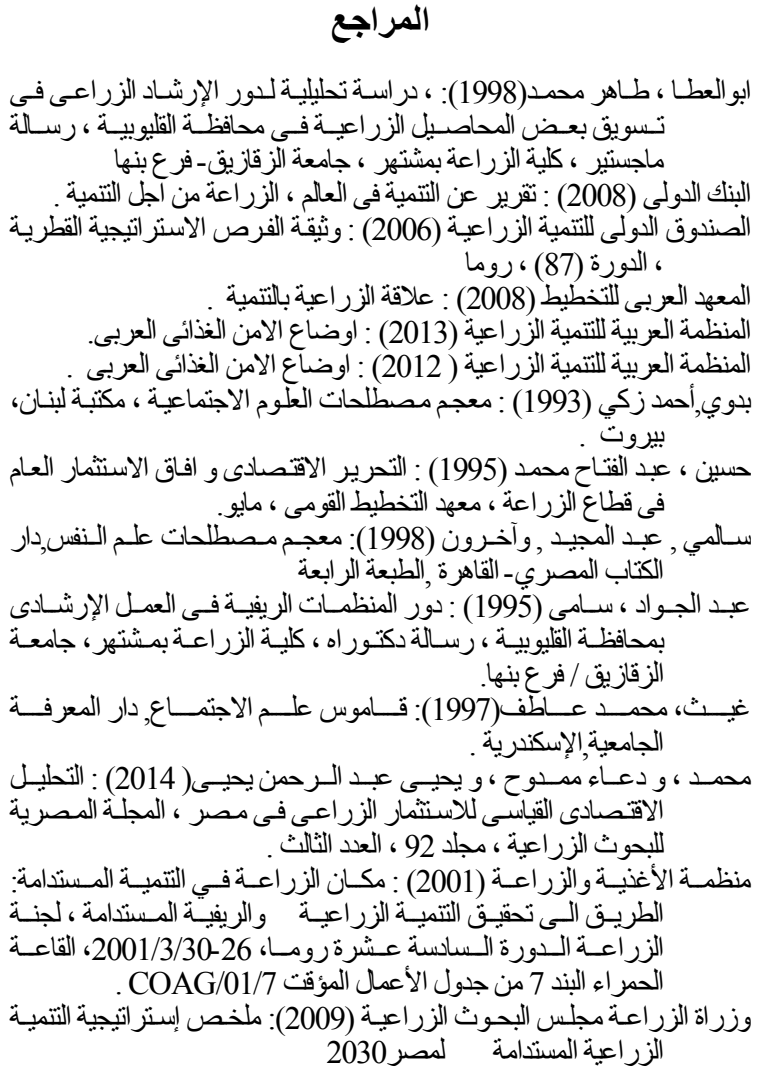

United Nations, Department of Economic and Social Affairs, Population Division. 2015. World population prospects: the 2015 Revision, DVD Edition.

World Bank. (2016). MENA economic monitor - April 2016: Syria: reconstruction for peace.

World Bank,( 2014). World development indicators. Highlights Featuring SDG Booklet.
وهذا يشبير إلى أن الدور الإجتماعى والإقتصادى للزبر اعنة في تنمية

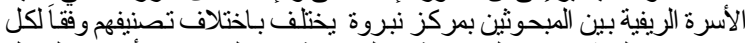

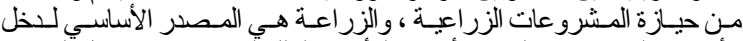

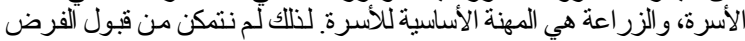

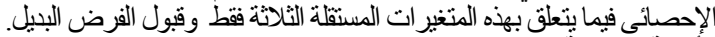
الأهمية التطييقية وتوصيات البحث:

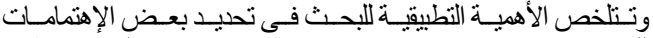

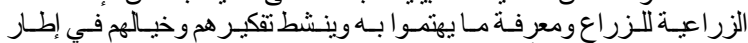

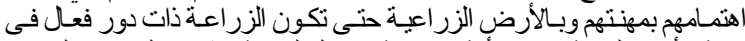

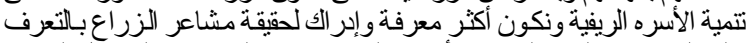

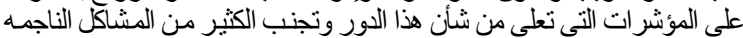

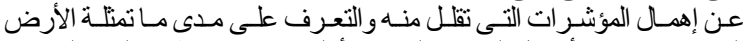

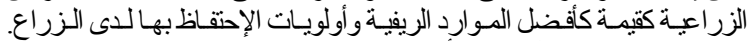

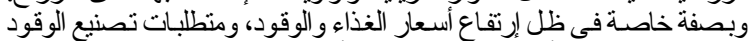

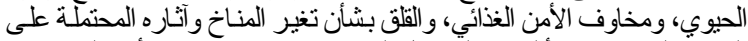

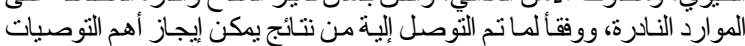

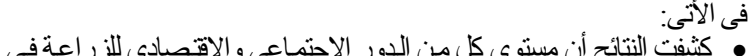

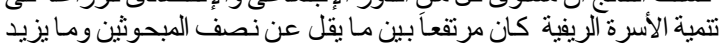

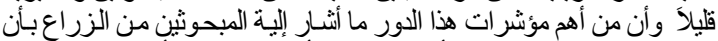

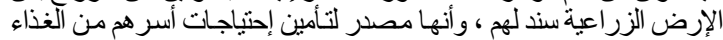

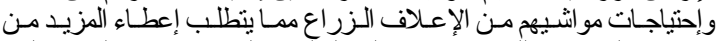

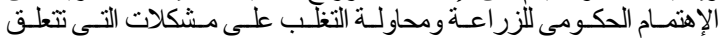

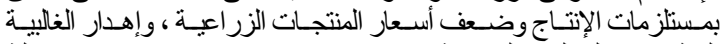

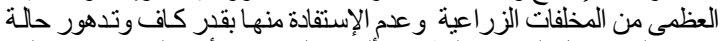

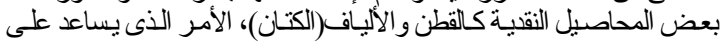

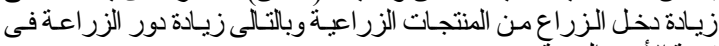
ت تلمية الأسره الريفية.

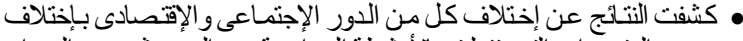

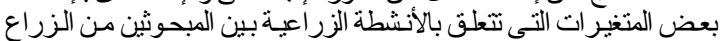

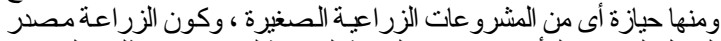

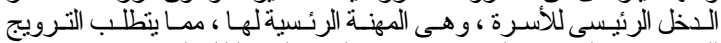

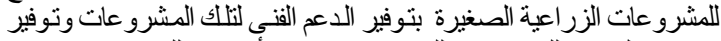

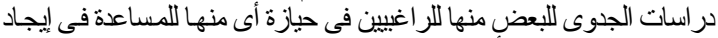
مصنادر نخل إضافي للأسر الريفية.

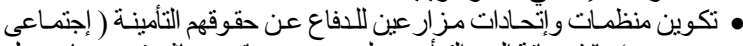

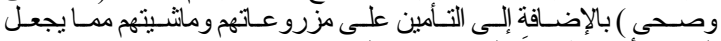
المزار ع أكثر إطمئناناً على حياتة وممتلكاتلة.

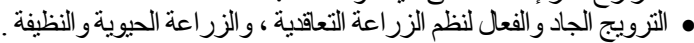

Socio-Economic Role of the Agriculture in the Development of the Rural Family in Biala District in Kafr El-Sheikh and Nabroh District in Dakahlia Governorate

Abo El-Saoud, M.

Agricultural Extension\& Rural Development Research Institute (AERDRI)-Agricultural Research Center

This research aims at identifying the social and economic role of agriculture in the development of the rural family, in addition to identifying the differences in the social and economic role of agriculture in the development of the family according to the different research area, and finally identifying the differences in both, social and economic role of agriculture in the development of the rural family according to the different the independent variables. The two villages were randomly selected from each District: the villages of al-Garidia, the Karakat in Bialla, and Tirah and Kafr al-Abhar in Nabroh district,(50) farmers from the total holders in each of the four villages were randomly selected. This resulted in the selection of (200) farmers representing the total sample. Interview with farmers using a questionnaire form designed to serve the research objectives after pre- testing. Several statistical analysis tools were used, including frequency, percentages, weighted average, and $\mathrm{T}$ test. to analysis the data. The most important results were as follows:* Both the social and economic role of agriculture in the development of the rural family among the respondents of the farmers varies according to the study area.* The level of the social and economic role of agriculture in the development of the rural family was high between $(49.0 \%, 57.0 \%)$, and $(44.0 \%, 64.0 \%)$ of the respondents of the farmers in Bialla and Nabroh districts respectively.* All the indicators of the social and economic role in the development of the rural family came at a weighted average of the highest relative weight of the theoretical measure, reflecting the relative increase of the role of agriculture in the development of the rural family*The most important indicators of the social role of agriculture in the development of the rural family are that the agricultural land is a subsidy to its owner, whatever the area between the respondents of the farmers in the research districts*The contribution of agriculture to safe food for the family among the respondents in in Bialla district, in return for the contribution of agriculture to the provision of feed for livestock in Nabroh district has been ranked on the top role of agriculture in the development of the rural family*There were differences in both the social and economic role of agriculture in the development of the rural family among the respondents when classified according to the small agricultural projects holding.* There were a differences in both the social and economic role of agriculture in the development of the rural family among the respondents in the Nabroh district when classified according to the possession of small agricultural projects, agriculture is the main source of household income, and finally agriculture is the basic profession of the family 